THE VIEW FROM INSIDE 



\title{
The View from Inside
} A French Communist Cell in Crisis

\author{
JANE JENSON \\ and GEORGE ROSS
}

UNIVERSITY OF CALIFORNIA PRESS BERKELEY - LOS ANGELES - LONDON 
University of California Press

Berkeley and Los Angeles, California

University of California Press, Led.

London, England

(C) 1984 by

The Regents of the University of California

\section{Library of Congress Cataloging in Publication Data}

Jenson, Jane.

The view from inside.

1. Parti communiste français. Cellule Danielle

Casanova. 2. Communist parties-France-Paris.

3. Communism-France. I. Ross, George, 1940-

II. Titk.

JN3007.C6J45 $1984 \quad 324.244^{\prime} 075 \quad 83-18189$

ISBN 0-520-04991-8

Printed in the United States of America

$\begin{array}{lllllllll}1 & 2 & 3 & 4 & 5 & 6 & 7 & 8 & 9\end{array}$ 
A JEAN

NOUS TE REMERCIONS POUR TON HUMOUR, TON INTELLIGENCE, ET TA GENEROSITE 
